\title{
System and technical basis for introduction of overpass aerotrain transport in the transport system of the region
}

\author{
Tatiana Vladimirova ${ }^{1,}{ }^{*}$, Viktor Sokolov ${ }^{1}$, and Sergey Sokolov ${ }^{2}$ \\ ${ }^{1}$ Siberian Transport University, Dusi Kovalchuk st., 191, 630049, Novosibirsk, Russia \\ ${ }^{2}$ ICC “Altaystroyinvest”, Sukhova st., 26, 656010, Barnaul, Russia
}

\begin{abstract}
The purpose of the paper is to demonstrate the adequacy of the technical and economic characteristics and consumer properties of the new overpass aerotrain transport to the geographical and climatic conditions of the region. It examines the opportunities and positive results of introducing a new mode of transport in the unified transportation system of the region in order to create favorable conditions for providing necessary transport sufficiency for its social and economic development.
\end{abstract}

\section{Introduction}

Most regions of Siberia in Russia have inadequate transport sufficiency for a harmonious social and economic development, for which it is necessary to form an effective transport system that is adequate to the landscape relief, climate pattern and the needs of business and population. For example, in the difficult geographical and climatic conditions of the Altai Mountains, it becomes necessary to abandon the formation of a traditional wheeled transport system that has technical, operational and economic performances that are not satisfactory for the time being. To ensure high efficiency of the transportation process in the transport system of the region, it is not enough to improve or modernize existing transport technologies, it is necessary to create fundamentally new transport technologies for the transportation of goods and passengers. New transport technologies should have the characteristics of creation and operation adequate for adverse climatic and landscape conditions: all-weather capability, high resistance to natural disasters (earthquakes, floods, snowfalls, hurricanes); should have lower operating costs than highways and railways; should easily fit into the urban environment; should be eco-friendly and not destroy the landscapes of unique territories. Studies have shown that such advantages can be enjoyed by overpass aerotrain transport - a complex group of related components, a symbiosis of a dynamic magnetic cushion, an overpass (screen) and a transport module, a project for the creation of which was proposed by a team of employees of LLC "Consulting and new technologies" and Siberian Aeronautical Research Institute named after S. A. Chaplygin in Novosibirsk. This paper describes the system and technical basis for introduction of overpass aerotrain transport in the transport system of the region.

${ }^{*}$ Corresponding author: vladimirovatat@yandex.ru 


\section{Preconditions for introduction of overpass aerotrain transport in the transport system of the Altai Republic}

Russia can retain control over the regions of Siberia, increase their investment attractiveness for business, and create favorable conditions for the life of the population, mainly by increasing the capitalization of these regions. Effective capitalization of the region assumes that its population, territory and production have a different, reliable, efficient, environmentally friendly, affordable transport system. "Transport, which provides material, energy and information flows together with energy communications and communication, creates the necessary conditions for the existence of modern society, progressive development and effective allocation of its production forces. World and domestic experience shows that the level, character and pace of the interconnected development of these components of the infrastructure complex can serve as an indicator of the development of the economy of the country and individual regions" [1].

Therefore, the growth of capitalization of the region directly depends on the formation and development of an effective unified transport system, which should be adequate to the geography, climate and social and economic state of the region. Besides, in the conditions of the formation of an innovative economy, it must ensure high efficiency of the transportation process and include innovative modes of transport. At the same time, the focus should not be only on improving or modernizing existing technologies, but rather on creating fundamentally new transport systems.

Western Siberia and the Altai Mountains are distinguished by the large dimensions of the territory, unfavorable climatic conditions, and uneven occupancy by the regions. The main landscape to the north of the Trans-Siberian railway is determined by countless rivers, lakes, marshes and other water barriers to transport. On the territory of the Altai Mountains, a hardly passable rock massif is added to these barriers. Taking into account not enough high growth rates of the economy of these regions and their large differentiation according to incomes of the population living there, one can say that one of the main projects for them should be the transport one.

The efficiency of the transportation process by traditional modes of transport is very low. "Let's give a few figures in order to explain the economic and environmental characteristics of modern transport: the average speed of cargo on the Trans-Siberian Railway is 9 $\mathrm{km} / \mathrm{h}$, as in the times of Catherine II on the Siberian route; in the passenger train, 25 tons of iron (compartment car, locomotive, rails) carry 1 ton of useful load; the "Tu-154" plane at the take-off takes up as much oxygen as the city with the population of 100,000 people; every second of the down time of the "Boeing" costs $\$ 1$; the more cars on the roads, the slower we move (you can instantly connect by the Internet with Canberra or San Francisco, and get to the center of your hometown for hours). $80 \%$ of pollution in big cities is provided not by thermal power stations and boiler houses, but by cars" [2]. "The lag of transport technologies from the development of public needs does not require proof. We live in the 21 st century, and we use the means of transportation invented in the 19th century, which are too slow and unreliable for our fast life. Time requires new, breakthrough solutions" [2].

The inclusion of a new type of transport that meets modern requirements for transport systems (reliability, speed, efficiency, environmental friendliness) into a single transport system of the region is currently an important scientific, technical and practical problem and requires the development and practical implementation of the system and technical basis for the organization of the transportation process by a new mode of transport and its effective introduction into the existing transport system of the region.

The most important technical and economic indicator for the introduction of transport in the transport system of the region is the estimated cost of its creation. Let's give an approx- 
imate cost of creating a route for various modes of transport: Bertin's Aerotrain: $€ 1.4$ to 5 million (depending on the engine version); TVR (tram on tires) by Caen and Nancy: $€ 12$ to 15 million; Highways: $€ 13.9$ million; TGV: $€ 15$ to 20 million (depending on population density in cities); Tram: $€ 12$ to 30 million (depending on population density in cities); Angers Tramway: $€ 28.6$ million; Light metro type VAL: $€ 65$ million; German Maglev: $€ 77$ million; Metro (large): $€ 90$ million; Japanese Maglev: $€ 93$ million; German "Sapsan": $€$ 37.1 million (Data of government contracts. The source: http://www.solidariteetprogres.org/documents-de-fond-7/science/article/revolution-destransports-rennes-nantes-en-20.html). Calculations by LLC "Consulting and new technologies" showed that the cost of $1 \mathrm{~km}$ of overpass aerotrain transport route will be $€$ 3-6 million, which is much lower than the cost of other high-speed lines and much lower than the cost of building of a railway line. Naturally, the cost depends on many factors and can vary significantly.

The spheres of influence between new and existing modes of transport in the region are manifested in the system of technical, economic and operational indicators. New modes of transport at the initial implementation are not an alternative to the existing ones, but supplement and improve the transport system of the region, increase the share of combined transportation. For example, a sharp change in the share of railway transport in the gross regional product may occur in case of significant changes in the regional economy. Therefore, serious changes in the share of railway transport in the transport services market will not happen with the appearance of new modes of transport (overpass aerotrain transport, ground effect vehicles, trains on magnetic suspensions, etc.). Most likely, the variety of the transport system will entail synchronous structural changes in the transport services market with the growth of the region's economy.

It is impossible to deny the need for variety as a condition and criterion for the efficiency and reliability of the functioning and development of production structures, production processes, and, in general, systems of any kind. The law of requisite variety of U. Ashby extends to technical, social and economic systems, including transport, etc. "It is believed that systems are more viable if their variety is higher, because in the existing variety of elements and connections of the system, there are forms of the potential of its adaptation to various variants of the future" [3].

An example of a very low level of variety in the transport system of the region is the Altai Republic. The entire transport system is represented mainly by road transport. Today, there are number of projects to build a railway from Biysk (Altai Territory) to the Altai Republic, to its capital - Gorno-Altaisk. It was planned to build it back in Soviet times, but did not have time. Already in 2007 the Novosibirsk design institute "SibGiproTrans" developed two versions of this railway line: 1) on the right bank ("Katunsky variant") of the Katun river, along the Chuysky tract ("Novosibirsk-Tashanta") with access to the suburb of Gorno-Altaisk (settlement Maimah). The length of the route is $122.6 \mathrm{~km}$, the cost of construction is $\$ 10.4$ billion $/ \mathrm{km}$. But today this price will probably be 2-3 times higher; 2) on the left bank of the Katun river, at the distance of about $10 \mathrm{~km}$ from it ("Field Option"), along the "old" Chuysk tract to the future Gorno-Altaisk station passing the village of Maima. The length of the road is $115.2 \mathrm{~km}$, the estimated cost of construction is $\$ 9.86$ billion $/ \mathrm{km}$. In both variants, the railway, according to the project, would pass through the territory of the Altai Territory on $90 \%$. That's why the Altai Territory is interested in this road and its continuation towards Mongolia and China no less than the Republic of Altai. It was planned to carry out not only passenger transportation, but also freight ones, including transportation of timber, metal ores, agricultural products, construction materials, etc.

Taking into account the current political and commercial relations between Russia and China, we can expect the revival of traffic along the federal motorway M52 "NovosibirskBiysk-Altai Republic" with access to Mongolia and China along the Chuysky Tract. This 
route is the basis of the transport network of the Altai Republic, the transport communications of which are largely tied to it. Traffic flows from Kuzbass, the Krasnoyarsk Krai, Khakassia and the Republic of Tuva come to it. The capacity of the route often does not cope with the existing freight and passenger traffic flows, especially in the tourist summer season and holidays.

A significant role in the capacity of the route is played by the development of travel industry in the Altai Republic, due to its beautiful mountain and water landscape. On the territory of the republic, there is a unique Teletskoye Lake, practically an "analog" of Lake Baikal. Dozens of mountain streams and rivers flow into the Teletskoye Lake, and only one Biya River flows from it, merging with Katun and forming one of the greatest rivers of Siberia - the $\mathrm{Ob}$. Unique healing opportunities exist here on the basis of velvet antler treatment, medicinal herbs, pure mountain air, local climate that is quite comfortable in a number of mountain valleys. It is not a surprise that many people call the Altai Republic "Siberian Sochi". "In the Altai Republic in 2017, 907 travel industry entities provided recreation for tourists ... In general, the number of places for simultaneous accommodation in collective accommodation facilities is 17517 , including year-round - 9716 units. During the summer tourist season in 2016, the load of CAF and Cottages was $80 \%$ on weekdays and $100 \%$ on weekends. Tourist infrastructure is represented throughout the Altai Republic... The tourist flow for 2017 amounted to 2.05 million people, an increase by 2016 was $3.2 \%$ " (http://altai-republic.ru/tourism/development/).

Recreational zones are expanding in the Altai Republic, including through the formation of small businesses in the area of mountain hiking and horse tourism, mountaineering, skiing, fishing and hunting. For extreme types of recreation, small aircraft and helicopters are increasingly used. However, the use of these modes of transport is hampered by difficulties in obtaining the necessary permits, including due to the special status of the Altai Republic as a territory bordering China, Mongolia and Kazakhstan.

The basis of the economy of the Altai Republic is agriculture (animal husbandry and horticulture), tourism, the share of income from which increases year by year. The Altai Republic is an agrarian republic with a sufficiently developed food industry. Animal husbandry prevails in agriculture, corn for silage and perennial grasses are cultivated in horticulture. The industry is based on the processing of agricultural products (lather, butter and cheese, meat). The Altai Republic has the richest energy resources; the annual hydropower potential is estimated at 80 billion $\mathrm{kWh}$. The following rivers have the most powerful energy potential: Katun (31 billion kWh), Argut (7.2), Chuya (7.1). In the republic, the use of mini and micro hydropower plants $(1-100 \mathrm{~kW})$ is promising for power supply to small consumers (shepherds, tourist camps, farms, agricultural processing enterprises).

Taking into account the fact that the Altai Republic shares borders with Mongolia, China, Kazakhstan and the fact that the vector of the international commonwealth of Russia has turned towards these countries, it is necessary to "back it up" with large-scale cooperative political, economic, cultural, sports and other events. One of the first "sites" of such cooperation could be the Altai Republic. Political, economic and cultural cooperation, especially with the involvement of young people, could contribute not only to reconciliation, but also to the development of friendly and business contacts of these countries that have recently emerged.

\section{Project for the creation of overpass aerotrain transport}

The most important factor hampering the social and economic development of the Altai Republic and the rise of its economy is transport. The Altai Republic is one of the six regions of Russia where are no railways and there is no certainty that railway transport will 
appear in the coming years. Excessively high cost of construction and operation of railway transport in extreme mountain conditions makes it necessary to create alternative modes of transport capable of solving many problems that cannot be solved by other modes of transport, in particular railway and road ones. In these conditions, overpass aerotrain transport proposed by V.G. Sokolov and A.N. Sereznov as an alternative transport, which refers to transport on a dynamic air cushion [4]. Today, it is possible to create on its basis ultra-high-speed lines that provide nearly aviation speeds on passenger lines up to 800-900 $\mathrm{km} / \mathrm{h}$.

Expansion of the transport system of the region due to innovative high-speed and ultrahigh-speed efficient modes of transport and transport communications contributes to its social and economic development, leads to an improvement in the dynamics of volumes and costs of transportation, and decrease in transport tariffs and the share of transport costs in the price of the final product. In this regard, overpass aerotrain transport can be attributed to effective modes of transport.

In the second half of the 20th century, the French engineer J. Bertin implemented a number of overpass aerotrain transport projects on a static magnetic cushion, which is created with the help of special fans, which inject air into the body of the transport module (vessel). In 1960, J. Bertin implemented the project "Aerotrain". His passenger module "Aerotrain" with 85 passengers was traveling at a speed of over $436 \mathrm{~km} / \mathrm{h}$.

Creation of a dynamic magnetic cushion is carried out by naturally forcing the airflow through the body and the wings of the transport module on the move (this effect is based on the screen effect). Engineer and aircraft designer R. Bartini, in the 1960s of the last century at the Siberian Aeronautical Research Institute named after S.A. Chaplygin (Novosibirsk) proposed overpass as an overground screen. The symbiosis of the dynamic magnetic cushion, overpass (screen) and transport module is the overpass aerotrain transport. The project for the creation of overpass aerotrain transport (a combination of a dynamic magnetic cushion, overpass aerotrain structure and a mobile module) was proposed by a team of employees of LLC "Consulting and new technologies" and Siberian Aeronautical Research Institute named after S.A. Chaplygin in Novosibirsk. This project is an example of system engineering, which is "the design, construction and commissioning of complex groups of related components that must work together under given conditions and are united by some type of interaction or interdependence with the goal of forming self-consistent and integral whole" (https://dic.academic.ru/dic.nsf/enc_colier/6500/).

Overpass aerotrain transport is a new communication system that includes a special kind of overpasses, along which at a height of 6 to 20 meters, and in special cases more, highspeed transport modules can move using the screen effect of dynamic magnetic cushion. The design of overpasses and mobile modules includes a number of new domestic technologies for designing, building, creating materials, operating, controlling of motion, etc. The module of the rolling stock of overpass aerotrain transport is a combination of a universal platform - a wing and a special passenger or cargo fuselage. As the last you can use the fuselages of decommissioned airliners at the first stages.

The authors obtained a patent (Sereznov A.N., Sokolov V.G. and others. Patent for invention № 2522189 “Ground effect vehicle - train”. Priority 10.11.2011, the patent holder is LLC "Consulting and new technologies") for overpass aerotrain transport, purged models of the transport module in the wind tunnel at the Siberian Aeronautical Research Institute named after S.A. Chaplygin, created 3D mathematical models and "printed" on 3D printer physical models of transport modules and overpasses. Based on the purging of models of rolling stock in the wind tunnel, an estimation of their optimal geometric parameters and power-to-weight ratio was obtained, and their rather high aerodynamic efficiency was revealed. The authors of the project need to complete an estimation of intellectual value of the project. For the final verification of the basic principles of the creation of overpass aero- 
train transport, it is necessary to build a sample (demonstrator) with a $1 \mathrm{~km}$ section of the route. The timeframe for creating such a test site is no more than 1.5-2 years, the costs are given in the Appendix. Today, research is continuing in the field of technical implementation of the project and the economic justification of its efficiency in several regions (Altai Territory, Altai Republic, Novosibirsk Region, Republic of Crimea).

The creation and application of overpass aerotrain transport will lead to the formation of new production and transportation complexes and the creation of socially oriented economic systems. "Introduction of the overpass aerotrain transport can become the basis for the formation of an innovative cluster that integrates no less than 30 innovative production structures, will allow to "compact" the space, uniting not only the cities, but also the territories ... With the help of the overpass aerotrain transport, it is possible to remove the employment problem of single-cities, design and create linear cities, run into one another along high-speed overpass aerotrain routes, to form compact cities with "built-in" transport infrastructures" [2].

"The positive results of introduction of overpass aerotrain transport are clear, but there is a problem of assessing its efficiency. Direct assessment of the efficiency of this innovative project is difficult, as well as any major innovative project. Traditional methods of assessment, when technologies have consumer properties that are absent in the old ones, are not suitable. There is a need for expert assessments, the quality of which depends on the competence of experts (it is difficult to choose them for this project because it is not even clear to which type of transport the overpass aerotrain transport is attributed)" [2].

The creation of the Novosibirsk - Barnaul - Biysk - Gorno-Altaisk - Tashanta (frontier point) overpass aerotrain route (and in the future to Mongolia, then through it to China) could become a transport bridge between the Siberian regions and in the future could become part of one of the future versions of the project "Silk Road": China - Mongolia - Russia. A variant of a direct passage through the western 50-kilometer rather complicated mountain section of the Russian-Chinese border to Urumqi (China), the capital of Xinjiang Uygur Autonomous Region (XUAR), is possible.

This proposal was once discussed in 1999 by the Government of the Novosibirsk Region with the Government of the XUAR and an Avant project was developed to build a road in this direction through the Kanas Pass [5]. Appropriate studies were carried out by the Russian and Chinese sides on the selection of possible directions for the motorway: "Kosh-Agach village - Argmandzhi village - Kanas Pass - Altai village (China) - Urumqi". The freight traffic was estimated at 500 vehicles per day. Today, this flow can be much more powerful, and the project can be adapted for the overpass aerotrain transport route. However, the project was rejected. The environmental groups were against it because the route passed through the plateau Ukok - plateau in the south of the Altai Republic, treating by the population of the republic as a "rest zone". In addition, demonstrations against this project took place in Gorno-Altaisk. It should be noted that the genetic memory is still preserved in the people of Altai that once in very remote historical times, China carried out genocide against the population of Altai, extirpated the Altaians.

The area along which the overpass aerotrain route will pass has a complex relief from the plains and foothills to the mountains and highlands. On the Novosibirsk - Biysk section, the route runs along the Ob River, crossing the Biysko-Chumyshskaya Hill. Where the flat part of the Altai shares a border with the Altai Mountains, the route goes to the territory of the Altai Republic, then crosses the Altai ranges (Cherginsky, Seminsky and others, reaching 1900-2000 $\mathrm{m}$ above sea level) and its intermountain hollows (Kuray and Chui, reaching $1500-1900 \mathrm{~m}$ above sea level).

A variety of climatic conditions accompany the route throughout its entire length. For the plain part of the zone of gravity of the route and to the northern spurs of the Altai ranges (Iolgo, Cherginsky, Seminsky), a temperate climate is typical (the average January tem- 
perature is about $-15^{\circ} \mathrm{C}$, and July is about $+18^{\circ} \mathrm{C}$ ). The climate here is rather humid (on average, precipitation is up to $650 \mathrm{~mm}$ ). It is harsher in the mountainous part of the gravity zone of the route and is characterized by sharp temperature variations. The section of the route behind the Seminsky pass is located in the arid zone, and in the high-mountainous region the route falls into an arid, sharply continental climate. The temperature variations of the Kuray and Chui basins have a range of variations from $+30^{\circ} \mathrm{C}$ in summer and $-40^{\circ} \mathrm{C}$ in winter.

The justification for the construction of the overpass aerotrain transport can be its high efficiency, first of all, due to its technical and economic characteristics of creation and operation for unfavorable landscape conditions:

- all-weather capability: overpass aerotrain transport will function effectively in unfavorable weather conditions (wind, rain, snow, ice, snow drifts, hail, fog, heat, sand and dust storms);

- in compare with the other land transport, overpass aerotrain transport has a high resistance to natural disasters (earthquakes, floods, snowfalls, hurricanes);

- overpass aerotrain transport route has lower operating costs than road routes and railways;

- low material consumption and high technological adaptability of the overpass aerotrain transport route makes its construction much cheaper than the construction of: ordinary railways in 2-3 times, high-speed railways in 10-20 times, highways in 5-8 times, monorail roads in 15-20 times, trains on a magnetic suspension in 30-40 times;

- overpass aerotrain transport route easily fits into the urban environment and can cross cities without creating special environmental problems, serving as an elevated metro;

- the construction of overpass aerotrain transport routes does not require embankments, tunnels and bridges, deforestation, damage to agricultural lands and water bodies. During their construction, excavation works are minimized, there is no damage to the soil and, what is important for this particular project, the overpass aerotrain transport route will not spoil the landscape of the unique territory, but will decorate it.

Today, a preliminary version of the Avant-project has been developed for the overpass aerotrain transport route River Station (metro station in Novosibirsk) - Akademgorodok (suburban district of Novosibirsk) as the starting section of the route Novosibirsk - GornoAltaisk. Novosibirsk is proposed as the starting point for the considered overpass aerotrain transport route, and this is not accidental, since almost all transport communications of Western Siberia "pull together" into this multimodal transportation hub (NMTH) [6].

The length of the route is about $25-30 \mathrm{~km}$. The travel time from the River Station to the Akademgorodok will be within $10-15$ minutes at a speed of $150-180 \mathrm{~km} / \mathrm{h}$, the potential carrying capacity of the line is no less than 100,000 passengers per day. The following passenger traffic data were used in the calculations: the first year of operation - 20 thousand passengers per day, about 7 million passengers per year. In the future, according to the project, passenger traffic is expected to increase by $5 \%$ per year. Standing time at wayside stops is up to 1-2 min. The capacity of the transport module of the overpass aerotrain transport operating on the route can be from 50 to 100 people, depending on the time of day and the passenger traffic. Planning horizon is up to 15 years. According to preliminary calculations, the payback period of the project will be within 5-7 years with the price for ticket River Station - Akademgorodok up to 50 rubles.

The total capital investments for the construction of the double-track overpass aerotrain transport route River Station - Akademgorodok into all structures and rolling stock will amount to $\$ 218,500$ thousand. In the future, in 3-4 years, with the development of the route and the expected growth in passenger traffic, there will be a need for an increase and possibly updating of the fleet of passenger modules. 
The Avant-project includes an estimation of cost of construction of experimentalindustrial routes, different variants of the rolling stock, and other expenses connected with provision of material and financial resources for the project. The transition from the Avantproject to a full-fledged investment project requires funding corresponding to such searching tasks. It should reflect the large-scale marketing research aimed at the future associated with the emergence of a new mode of transport. It is necessary to carefully study the necessary volumes of capital costs for technical design, creation of a full-fledged operating domain with all its infrastructure and engineering support, etc. According to the answers of Ministry of Transport to our requests for project implementation opportunities, it will be difficult to implement it without the participation of higher government entities. For example, the project of J. Berten was personally supported by the President of France Georges Pompidou, and after his death, President J. Chirac made a bid for high-speed railway transport and J. Bertin's project was closed.

Financial support of the project can be achieved through the establishment of a publicprivate partnership with $50 \%$ participation of government entities, and the remaining $50 \%$ of funds will be attracted in the form of debt capital (for example, a 10-year bank loan at no more than $12 \%$ per annum). Mixed financing (state credit, foreign investments, investments of international organizations, venture capital) is possible.

As a result of the calculations, the following values of integral indicators of the project's economic efficiency were obtained: IRR - internal rate of return - 20\%; Profitability (profit/expenses) - 50\%; NPV - net present value - $\$ 40$ million; payback period up to 7 years.

The implementation of the project for the construction of a high-speed overpass aerotrain transport route along the route Novosibirsk - Gorno-Altaisk will solve many transport problems in the south of Western Siberia. The creation of overpass aerotrain transport route in the region has a systemic character, has a synergetic effect, combining the efforts of various project participants: metal for supports of the route can be produced by the Kuzbass enterprises; cement for supports can be supplied by factories in Isktim and Topki. The range of potential engine manufacturers for rolling stock is also wide. Altai, Omsk, Perm, Chelyabinsk manufacturers can take part in the deliveries, among them Altai Motor Plant and Omsk Plant named after Baranov. Such enterprises as Novosibirsk Aviation Production Association named after Chkalov, Production Association "Polet" in Omsk, and other Russian companies can produce bodies of rolling stock for overpass aerotrain transport. Today, they are loaded much less than their potential. The mathematical support of the systems for the design and management of overpass aerotrain transport can be carried out by research and design organizations in Novosibirsk, Tomsk, Omsk, Krasnoyarsk, etc. In this regard, so far Russia, and in particular Siberia, can take on nearly whole complex of noted practically significant problems, which can serve its development and reduce the outflow of population from its regions.

\section{Conclusion}

The authors' research in the field of the formation of transport systems in Siberia and the Far North of Russia revealed the problems of their insufficient transport availability, demonstrated low technical and economic indicators and consumer properties of modern traditional modes of transport, and showed the need to modernize transport systems by creating innovative transportation technologies. The paper shows the prerequisites for the necessity to introduce overpass aerotrain transport into the transport system of the Altai Republic and demonstrates the adequacy of the technical and economic characteristics and consumer properties of the new transport to the geographic and climatic conditions of the region. 


\section{References}

1. A.M. Prizmazonov, Railway transport system. Efficiency, reliability, safety (Zheldorizdat, 2002)

2. T.A. Vladimirova, A.N. Sereznov, V.G. Sokolov, S.A. Sokolov, Siberian Financial Schoo 1, 3-6 (2015)

3. T.A. Vladimirova, V.G. Sokolov, A.E. Unitsky, New technologies in the creation and development of transport systems (Polygraph, Khanty-Mansiysk, 2008)

4. A.N. Sereznov, V.G. Sokolov, S.A. Sokolov, ECO 12, 113-125 (2014)

5. A.A. Valeev, V.G. Sokolov, Development of the motor transport network of the Altai Republic (Intelsis, Novosibirsk 2000)

6. K.L. Komarov, R.Z. Talipov, V.G. Sokolov, V.K. Bashkov, S.A. Maksimov, Novosibirsk multimodal transportation hub (Publishing House of SSTU, Novosibirsk 2001) 